\title{
Geotrichopsis mycoparasitica gen. et sp. nov. (Hyphomycetes), a new mycoparasite
}

\author{
S. S. TZEAN \\ Department of Plant Pathology and Entomology, National Taiwan University, Taipei Taiwan, 10764, R.O.C. \\ R. H. ESTEY \\ Department of Plant Sciences, Macdonald College of McGill University, Ste Anne de Bellevue, Quebec H9X 1CO, Canada
}

Geotrichopsis mycoparasitica is described as the type species of a new genus, characterized by a rapid growth rate and white, floccose,
woolly, patchy, raised pustular colonies. G. mycoparasitica forms arthroconidia by disarticulation of undifferentiated hyphae, and
oblong-, spindle-, lobed-, or irregularly-shaped thick-walled chlamydospores. It has dolipore septa and pore cap structures and is
capable of parasitizing many fungi. It differs from some superficially closely related genera such as Arthrographis, Geotrichum,
Mauginiella and Trichosporon in microscopic and macroscopic characters, septal structure, and/or the teleomorphic affinity.

Formation by disarticulation or segmentation of undifferentiated hyphae or differentiated conidiophores is the simplest and most primitive form of conidial production in the anamorphs of some Ascomycotina and Basidiomycotina (von Arx, 1977; Butler \& Petersen, 1972; de Hoog et al., 1986; Kreger-Van Rij, 1973; Sigler \& Carmichael, 1976; Walt \& Hopsu-Havu, 1976). However, the apparent uniformity in morphology and conidiogenesis in no way indicates natural phylogenetic or taxonomic relationships. Therefore, it is not surprising that form-genera like Geotrichum, Oidium and Trichosporon, with the capacity of producing arthroconidia by fragmentation of hyphal or conidiogenous elements, have become the dumping grounds for fungi of heterogeneous origins (Sigler \& Carmichael, 1976; de Hoog et al., 1986). An example is Geotrichum candidum Link, which has at least 52 synonyms (Carmichael, 1957). This greatly confuses and complicates assessment of the status of fungi which morphologically or physiologically resemble one another. Sigler \& Carmichael (1976) studied and compared the holothallic and enterothallic fungi and proposed a tabular key to related genera such as Coremiella, Bahusakala, Scytalidium, Geotrichum, Mauginiella, Sporendonema, Malbranchea, Chrysosporium, Ovadendron, Arthrographis, Briosia, Arcuadendron and Ptychogaster. These could be separated by criteria such as conidiophore differentiation, conidial width, pigmentation, connective or intervening cells, presence or absence of synnemata, and the teleomorph connexions (Sigler \& Carmichael, 1976). As for non-yeast-like arthroconidial states of Basidiomycotina, currently no form-genera are known. They were temporarily classified into four separate groups according to the growth rate, colony texture, curvature of conidiogenous hyphae, development of separating cells between maturing arthro- conidia, and condensation and septation of hyphal protoplasm (Sigler \& Carmichael, 1976).

During study of the nematode-trapping fungi Arthrobotrys oligospora Fresen. and Dactylella cionopagum Drechsl. certain culture plates became contaminated by an unknown arthric fungus. Some of the conidia and conidiophores of the nematode-trapping fungi entwined by the arthric fungus showed signs of disintegration. With a view to exploring the identity of the arthric fungus and its mycoparasitic ability, experiments were then initiated. The fungus turned out to be a basidiomycete anamorph, because it has dolipore septa with a pore cap structure. It is also a destructive mycoparasite (Tzean \& Estey, 1991). It grew rapidly with dense, patchy, woolly, raised pustular colonies, formed dry arthroconidia by disjunction at septa of hyaline, undifferentiated fertile hyphae. These morphological characteristics are comparable to group I, anamorphic states of Basidiomycotina (Sigler \& Carmichael, 1976), but differed from any existing genera of Hyphomycetes, Deuteromycotina. It is described as a new genus and new species because there is currently no suitable form-genus available for its accommodation (Sigler \& Carmichael, 1976; de Hoog et al., 1986; von Arx, 1981b).

\section{MATERIALS AND METHODS}

Pure cultures were obtained from single conidia or conidial masses picked from the parasitized nematode-trapping fungi, Arthrobotrys oligospora, Dactylella cionopagum, by sterile microglass needles under a $50 \times$ stereomicroscope. For morphology and structure it was grown on potato dextrose agar (PDA), corn meal agar (CMA) (Difco), or phytone yeast extract agar (PYEA) (Carmichael, 1962), and incubated at 
$25^{\circ} \mathrm{C}$ in the dark. The growth rate, colony texture, and microscopic features of the fungus were measured and recorded from $5 \mathrm{~d}$ to 1 month. Kornerup \& Wanscher (1978) was followed as a colour standard. Pieces of agar disc from the colonies were processed for transmission and scanning electron microscopy by previously described methods (Tzean \& Estey, 1978). Preliminary transmission electron microscopy showed it to have dolipore septa and septal-pore cap structures, both indicative of basidiomycetous affinity. For comparative studies, several Basidiomycetes, Phlebia radiata Fr.:Fr. (UAMH No. 3776, 3787), Antrodia albida (Fr.: Fr.) Donk (DAOM 52343), Coriolus versicolor (L.:Fr.) Quél. (DAOM 211504), Coriolellus serialis (Fr.:Fr.) Murr. (DAOM 37862), Coriolopsis gallica (Fr.:Fr.) Quél. (DAOM 22274), Pleurotus ostreatus (Jacq.: Fr.) Kummer (DAOM 140072), Polyporus adustus (Wild. :Fr.) Karst., all with the capacity to produce arthroconidia and thus similar taxonomic affinities, were also cultivated under the same conditions as the new mycoparasite. In addition, Mauginiella scaettae Cav. (IMI 243503), Geotrichum candidum, and two Geotrichum strains (UAMH No. 448, 507) were also included.

\section{RESULTS AND DISCUSSION}

\section{Geotrichopsis Tzean \& Estey, gen. nov.}

Coloniae celeriter extendosae, compactae, fragmentae, floccosae, lanatae, subelevatae pustulatae, cum leviter distincta straminis odore. Mycelium album. Hyphae hyalinae, irregulariter vel dichotome ramificantes, erectae vel decumbentes, septa cum doliporo-

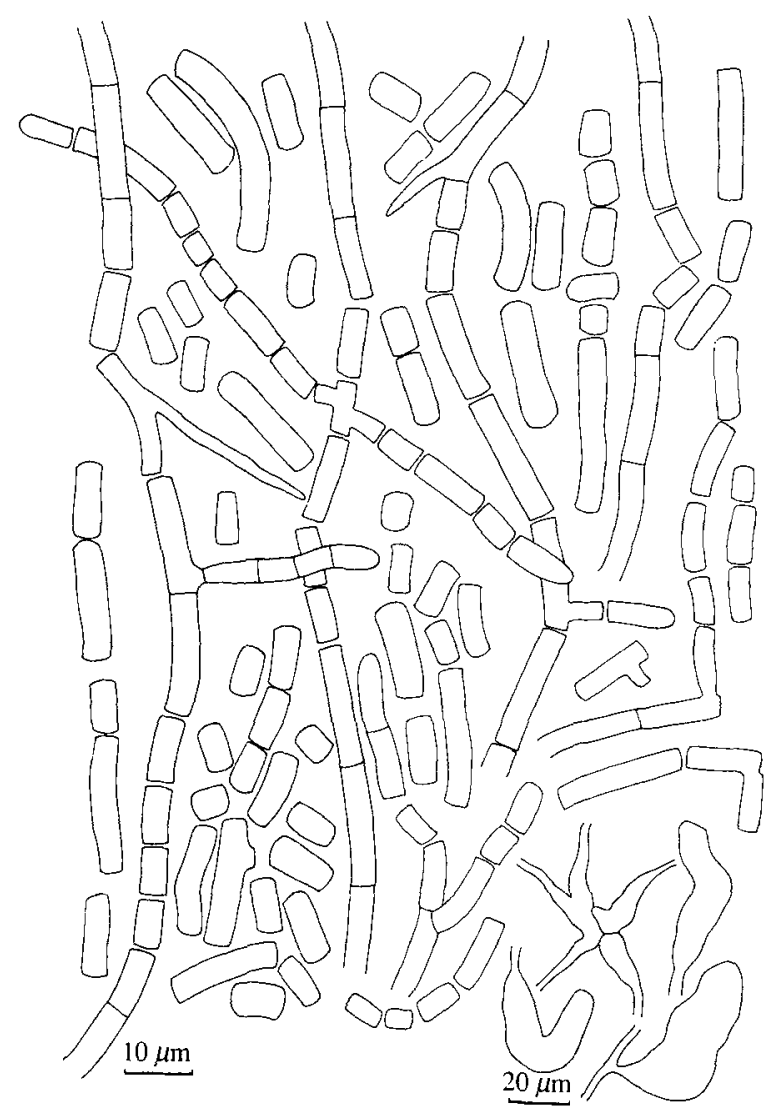

Fig. 1. Morphological characteristics of Geotrichopsis mycoparasitica. Illustrations depicting disarticulation of fertile hyphae, arthroconidia, and chlamydospores. parenthesibus structuris, carentes fibularum connexas. Conidiophorum destitutum. Conidia holoarticulata genita ab schizolyticis, non-septata, hyalina. Chlamydospora intercalaris vel terminalis, oblonga, fusoidea, lobata vel irregularis, Parasitica in vario fungo.

Sp. typ.: Geotrichopsis mycoparasitica Tzean \& Estey.

Geotrichopsis mycoparasitica Tzean \& Estey, sp. nov.

(Figs $1-10$ )

Coloniae rapide extendosae, compactae, fragmentae, floccosae, lanatae, subelevata pustulae, cum leviter distincta straminis odore. Mycelium album. Hyphae hyalinae, 1-6.4 $\mu \mathrm{m}$ latae, irregulariter vel dichotome ramificantes, erectae vel decumbentes, septa cum doliporoparenthesibus structuris, carentes filbularum connexas. Conidiophorum destitutum. Conidia holarticulata, genita ab schizolyticis, non-septata, hyalina, laevia, cylindrica, extremo truncata vel leviter convexa, 3-17 $\mu \mathrm{m}$ longa, $2-3.2 \mu \mathrm{m}$ lata. Chlamydospora intercalaris vel terminalis, oblonga, fusoidea, lobata vel irregularis, 45-60 $\times 8-19 \mu \mathrm{m}$. Parasitica in fungi vario.

Holotypus ex nematode-trapping fungi contamino culturae laminae, Macdonald College, McGill University, May 1974, PPH8, isotypus IMI 348371; New York Botanical Garden.

Colonies on potato dextrose agar (PDA) expanding rapidly, $8.0-8.5 \mathrm{~cm}$ diam. in $10 \mathrm{~d}$ at $25^{\circ}$ without illumination, white, floccose, woolly, exudates or soluble pigments absent, reverse uncoloured, yellowish white to light yellow, or light orange (M. 4A2-5, 5A.5-5), with a less distinct straw odour. Colony growth rate and texture on phytone yeast extract agar (PYEA) were comparable to that on PDA, but were more distinctly floccose. Colonies on PDA in 3-4 wk dense, woolly, smooth, pustular, reverse tan in colour (Fig. 2). Mycelium white. Hyphae hyaline, $1-6.4 \mu \mathrm{m}$ wide, irregularly or dichotomously branched, mostly superficial, partly decumbent, rarely submerged (Fig. 3), septate with dolipore-parenthesome structures (Fig. 10), without clamp connexions. Conidiophores micronematous or lacking. Conidia dry, holoarthric, produced by schizogenous disarticulation (Figs 3-5), aseptatae, hyaline, smooth, thin-walled, cylindrical, barrel-, oblong-, T-, wedge-, or bizarre-shaped, straight or slightly curved (Figs 6-8), initially truncate at each end, later rounded-off, discoid (Fig. 7), 3-17 $\mu \mathrm{m}$ long, 2-3.2 $\mu \mathrm{m}$ wide. Chlamydospores intercalary or terminal, ellipsoidal, spindly, lobed, or irregular in shape, $45-60 \times 8-19 \mu \mathrm{m}$, thick-walled (Fig. 9). Parasitic on various fungi.

Specimen examined: isolated from naturally-infested nematodetrapping fungi, Arthrobotrys oligospora (Fresen.) Drechsl., A. robusta Dudd., Macdonald College, McGill University, May 1974, holotype PPH 8 (dried culture) derived from PPH8E (living culture) was deposited in Department of Plant Pathology and Entomology, National Taiwan University, Taipei, Taiwan, R.O.C. PPH8E was also deposited in culture Collection and Research Center (CCRC 32451), Hsinchu, Taiwan, R.O.C. Isotypes in NY and as IMI 348371.

Geotrichum was erected by Link in 1809 to accommodate a single species, $G$. candidum Link, which was characterized by thin colonies consisting of a hyaline, septate, mycelium, and formation of arthroconidia by disarticulation of the fertile hyphae, usually in basipetal succession (Carmichael, 1957). Recently, de Hoog et al. (1986) redefined and emended the 

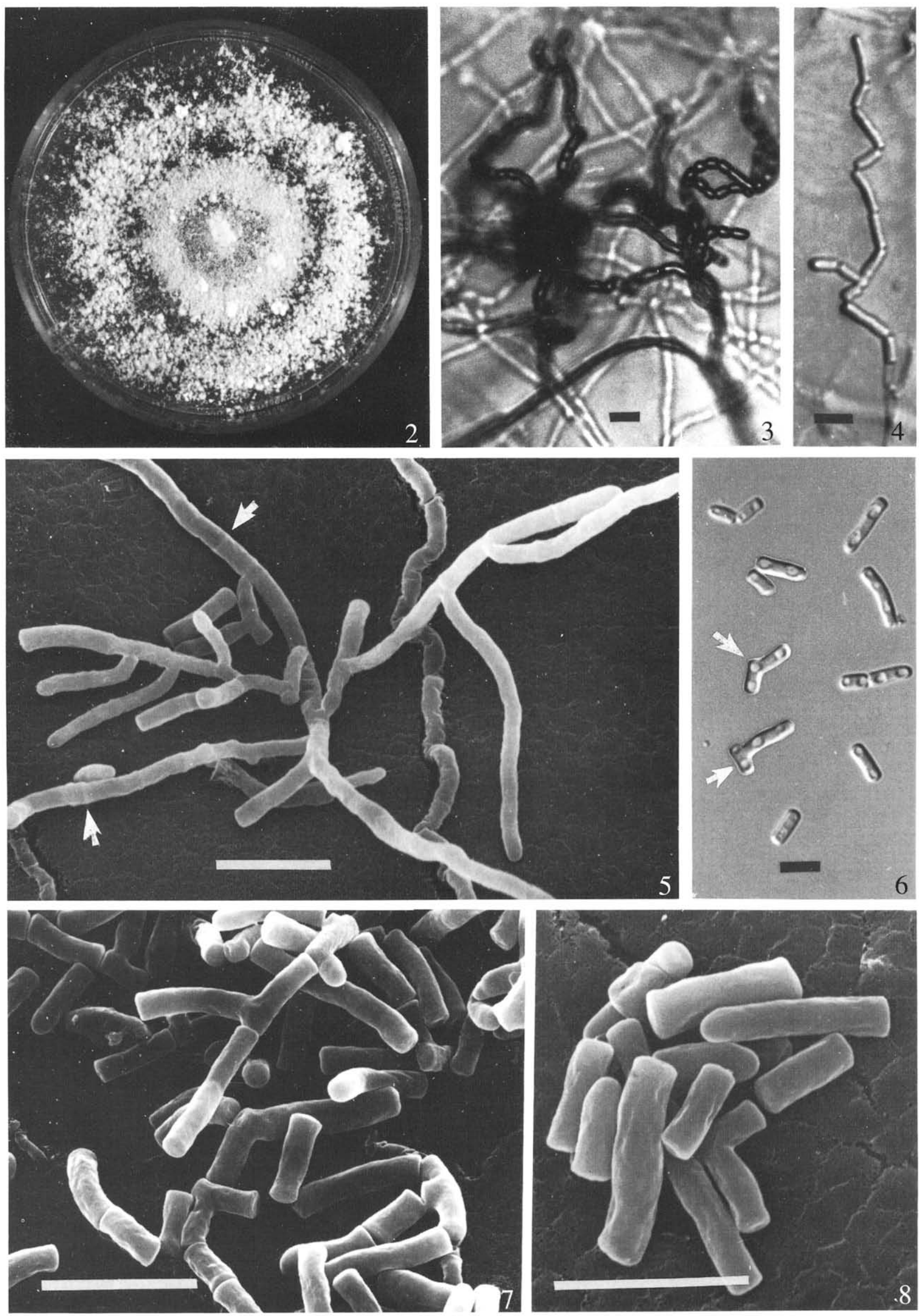
genus on the basis of morphological and physiological characteristics and DNA relatedness. The circumscription of Geotrichum now comprises Hyphomycetes with colonies white, farinose, hairy, usually dry, detached or disturbed becoming slimy; hyphae hyaline, with di- or trichotomous apical branches at the colony margin; septa with micropores (Steele \& Fraser, 1973); conidiogenesis with growth of the conidiogenous apparatus arthric, sympodial, percurrent, blastic, or endosporic; with endomycetous affinity. Currently 23 species of Geotrichum have been recognized and described, fourteen with Dipodascus and two with Galactomyces teleomorphs (de Hoog et al., 1986). Geotrichopsis is superficially most closely related to Geotrichum, based on the arthrosporic morphology and conidiogenesis. However, Geotrichopsis does not have any blastic, endosporic, percurrent or sympodial conidogenous capacity as Geotrichum does (de Hoog et al., 1986). Moreover, the colony textures of Geotrichopsis are woolly, floccose, patchy or raised pustular, in contrast to Geotrichum which has colonies which are decumbent, thinly spreading over the agar, usually dry but possibly becoming slimy when disturbed, covered with spine-like aggregates, with dichotomous apical branches at the margin. In addition, Geotrichopsis has dolipore, pore cap structures, indicating basidiomycetous affinity, while Geotrichum is known to have endomycetous affinity, with micropore septa typical of Ascomycetes (Carmichael, 1957; Sigler \& Carmichael, 1976; de Hoog et al., 1986). The distinction between the two genera is striking.

In conidiogenesis Geotrichopsis mycoparasitica resembles Mauginiella scaettae Cav., a causal agent of date palm spadix and inflorescence rotting (Nicot, 1972; von Arx, 1981a), and the only species known in the genus (Sigler \& Carmichael, 1976; von Arx, 1981 b). G. mycoparasitica has unicellular hyaline conidia of the same width as fertile hyphae, dolipore septa-parenthesome structures, in contrast to $M$. scaettae in which conidiogenous cells are differentiated, erect, simple or branched, broader $(5-9 \mu \mathrm{m})$ than repent $(1.5-2.5 \mu \mathrm{m})$ and aerial (3-4 $\mu \mathrm{m})$ hyphae and conidia which are 1-6-celled, with a central pore of ascomycetous affinity (von Arx, 1981a). Examination of a strain of M. scaettae (IMI 243503) showed four types of structures: (1) hyphae thin, hyaline, approximately $1.9 \mu \mathrm{m}$ in width, flattened on the agar surface; (2) hyphae moderate in width, hyaline, mostly decumbent, disarticulating into segments, oblong, 4.8-6.7 $\mu \mathrm{m}$ wide, 14.3-16.2 $\mathrm{mm}$ long; (3) spores spherical, in chains, ca $19 \mu \mathrm{m}$ diam., formed on the aerial hyphae at the apices, thick-walled, with dense cytoplasm, pale brown in colour, some with an abscission scar; (4) arthroconidia, aerial in chains, with dense cytoplasm; some detached spores with a truncate basal or lateral scar. Mauginiella scaettae, based on IMI 243503, only shows superfical similarity to G. mycoparasitica in colony texture. The predominant aerial arthroconidia of $M$. scaettae noticeably differ from those of G. mycoparasitica in size, colour, septation and the presence of scars. The conidia and their genesis in $M$. scaettae are closer to the anamorphic states of powdery mildews than to G. mycoparasitica.

Sigler \& Carmichael (1983) validated the genus Arthrographis and provided a key to the three currently recognized species, A. kalrae (Tewari \& Macpherson) Sigler \& Carmichael, A. cuboidea (Sacc. \& Ell.) Sigler, and A. lignicola Sigler. A. kalrae has a Pithoascus lageronii von Arx ascomycetous teleomorph. Conidiogenous hyphae in Arthrographis are in dendroid tufts and are narrow, generally $1.5-3.0 \mu \mathrm{m}$ wide, branched or unbranched, and divided basiptally or at random to form arthroconidia. Occasionally, arthroconidia formed by segmentation of undifferentiated hyphae occur. There are no separating cells, disjunctors or connectives between seceding conidia. Arthrographis differs markedly from Geotrichopsis, the latter lacking differentiated arborescent conidiogenous hyphae, having dolipore septa, and a rapid growth rate, different colony characteristics and microscopic features.

Geotrichopsis and Trichosporon both produce arthroconidia, but in Trichosporon usually blastic, sympodulo-, enterothallic and annellate structures are formed (Carmo-Sousa, 1970; de Hoog et al., 1986; Salkin et al., 1982). In Trichosporon, colonies are creamy, mucoid, glistening, coherent, flat, spreading, raised in the centre (umbo), margin fringed with pseudomycelium or true mycelium (Carmo-Sousa, 1970). The separation of Geotrichopsis and Trichosporon should be maintained, although T. cutaneum (de Beurm., Gougerot \& Vaucher) Ota has dolipore septa and develops a red reaction to Diazonium Blue B salt which is characteristic of basidiomycetous affinity (Kreger-Van Rij, 1973; Walt \& HopsuHavu, 1976). Recently several Trichosporon species, e.g. $T$. fermentans Diddens \& Lodder, T. klebahnii Stautz $(=T$. penicillatum Carmo-Sousa), T. sericeum (Stautz) Diddens \& Lodder, $T$. capitatatum Diddens \& Lodder, have been recombined as Geotrichum fermentans (Diddens \& Lodder) von Arx, G. klebahnii (Stautz) Morenz, G. sericeum (Stautz) de Hoog, M. Th. Smith \& Guého (teleomorph Dipodascus ovetensis (Palaez \& Ramírez) von Arx), G. capitatum (Diddens \& Lodder) von Arx (teleomorph Dipodascus capitatus de Hoog, M. Th. Smith \& Guého), respectively, according to a revised circumscription (de Hoog et al., 1986).

Geotrichopsis mycoparasitica differed in macro-, and microscopic features from anamorphs of Phlebia radiata, Antrodia albida, Coriolus versicolor, Coriolopsis gallica, Pleurotus ostreatus, Polyporus adustus and two strains of Geotrichum spp. (UAMH No. 448,507$)$ shown in a comparative study. G. mycoparasitica also showed a noticeable difference from the above-mentioned fungi in general proteins and enterase isozyme profiles in electrophoresis (Tzean \& Estey, unpubl.). G. mycoparasitica fits

Figs 2-8. Morphological and structural characteristics of Geotrichopsis mycoparasitica. Figs 3, 6, Bar =10 $\mu \mathrm{m}$, Figs 4, 5, 7, 8, Bar $=$ $5 \mu \mathrm{m}$. Fig. 2. Colony on PDA in three weeks. Fig. 3 Fertile aerial hyphae disarticulating into arthroconidia in chains. Fig. 4. Repent hypha disjunction into arthroconidia, in more or less zig-zag arrangement. Arthroconidia cylindrical, variable in length. Fig. 5. Scanning electron micrograph of fertile, branched hyphae, septation barely visible (arrows). Fig. 6. Most of the released conidia cylindrical, both ends discoid, usually with distinct vacuoles, while some conidia are T-, or wedged- shaped (arrows), depending on the portion where fission taking place. Fig. 7. Scanning electron micrograph depicting the segmentation of fertile hyphae into arthroconidia, intervening or connective cells lacking. Fig. 8. Arthroconidia mostly bacilloid or cylindrical, smooth-walled (SEM). 

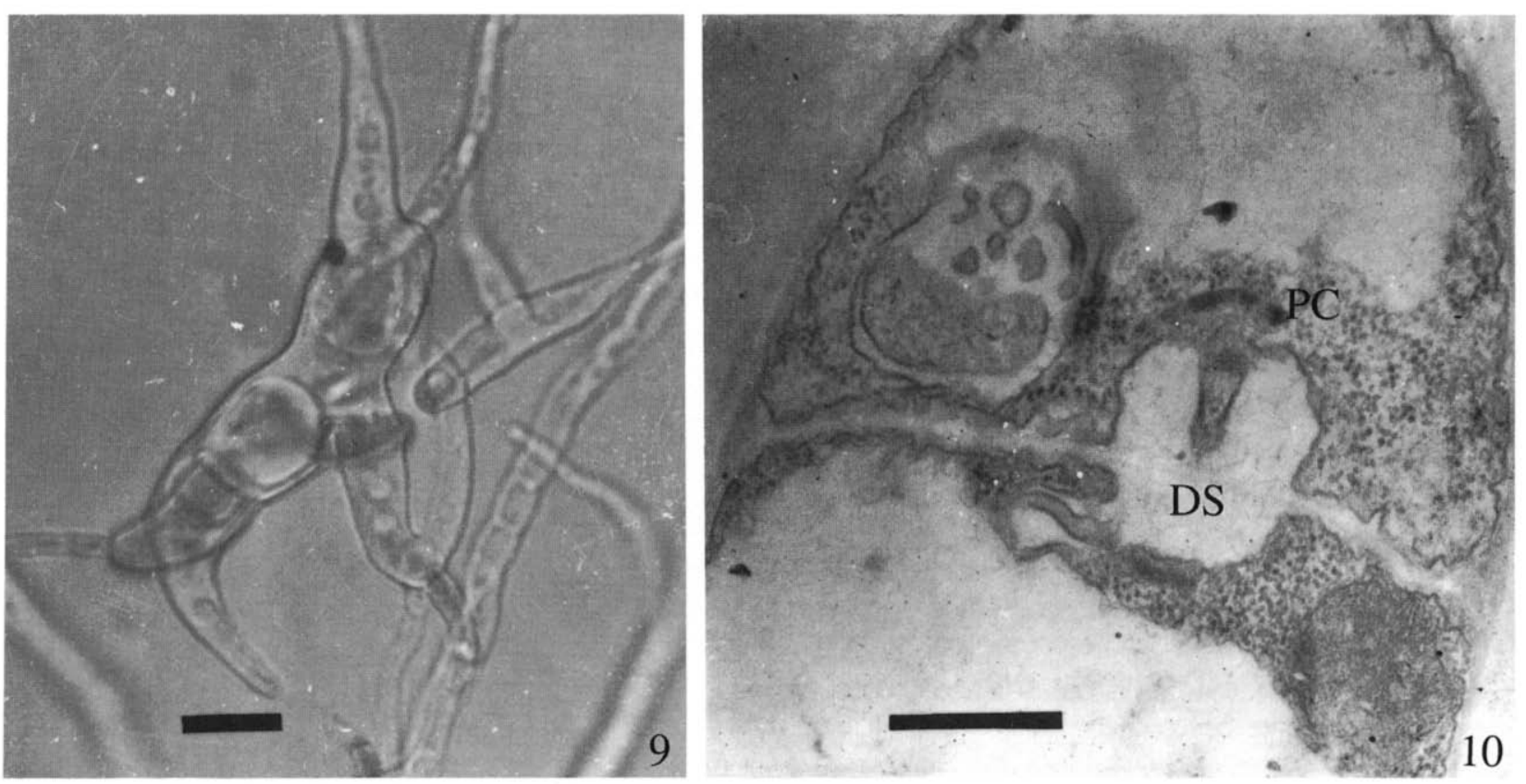

Figs 9-10. Morphological and structural characteristics of Geotrichopsis mycoparasitica. Fig. 9. Broad, spindly-shaped chlamydospores. Bar $=10 \mu \mathrm{m}$. Fig. 10. Oblique section showing the dolipore septa (DS) and portion of pore cap (PC) (TEM). Bar $=0.5 \mu \mathrm{m}$.

quite well into the gross morphological description of a tentatively designated group I, anamorphic state of Basidiomycotina (Sigler \& Carmichael, 1976), but no generic or specific names for it have yet been proposed.

This work was supported in part by National Science Council, R.O.C., grant NSC-79-0409-B002-45. The authors are indebted to Dr J. W. Carmichael and Mrs Patricia Le Clair for sending some Geotrichum spp. and some strains of Basidiomycetes for comparative studies; to Dr B. C. Sutton for critical review and invaluable assistance in preparation of the manuscript; to $\mathrm{Dr}$ J. C. Liao for preparing the Latin diagnosis; to Mr J. L. Chen for the illustration and to Miss W. F. Kao for typing the manuscript.

\section{REFERENCES}

Arx, J. A. von (1977). Notes on Dipodascus, Endomyces and Geotrichum with the description of two new species. Antonie van Leeuwenhoek 43, 333-340. Arx, J. A. von (1981a) On Manginiella scaettae. Sydowia 34, 42-45.

Arx, J. A. von (1981 b). The Genera of Fungi Sporulating in Pure Culture. 3rd edn. Germany: J. Cramer.

Butler, E. E. \& Petersen, L. J. (1972). Endomyces geotrichum a perfect state of Geotrichum candidum. Mycologia 64, 365-374.

Carmichael, J. W. (1957). Geotrichum candidum. Mycologia 49, 820-830.
Carmichael, J.W. (1962). Chrysosporium and some other aleuriosporic Hyphomycetes. Canadian Joumal of Botany 40, 1137-1175.

Carmo-Sousa, L. Do (1970). Genus II Trichosporon Behrend. In The Yeasts, a Taxonomic Study (ed. J. Lodder), pp. 1309-1352. Amsterdam, Netherland: Noth-Holland Publishing Company.

Hoog, G. S. de, Smith, M. Th. \& Guého, E. (1986). A revision of the genus Geotrichum and its teleomorphs. Studies in Mycology 29, 1-130.

Kornerup, A. \& Wanscher, L. H. (1978). Methuen Handbook of Colour. London: Eyre Methuen I.td.

Kreger-van Rij, N. J. W. (1973). Endomycetales, basidio-mycetous yeasts, and related fungi. In The fungi IV A (ed. G. C. Ainsworth, F. K. Sparrow \& A. S. Sussman), pp 11-32. London, U.K.: Academic Press.

Nicot, J. (1972). Manginiella scaettae Cav. Pourriture de l'inflorescence du palmier-dattier. Revue de Mycologie 24, 1-6.

Salkin, I. F., Gordon, M. A., Samsonoff, W. A. \& Reider, C. L. (1982). Blastoschizomyces pseudotrichosporon, gen. et sp. nov. Mycotaxon 14, 497-504.

Sigler, L. \& Carmichael, J. W. (1976). Taxonomy of Malbranchea and some other Hyphomycetes with arthroconidia. Mycotaxon 4, 349-488.

Sigler, L. \& Carmichael, J. W. (1983). Redisposition of some fungi referred to Oidium microspermum and a review of Arthrographis. Mycotaxon 18, 495-507.

Steele, S. D. \& Fraser, T. W. (1973). The uitrastructure of Geotrichum candidum hyphae. Canadian Joumal of Microbiology 19, 1507-1512.

Tzean, S. S. \& Estey, R. H. (1978). Schizophyllum commune Fr. as a destructive mycoparasite. Canadian Journal of Microbiology 24, 780-784.

Tzean, S. S. \& Estey, R. H. (1991). Geotrichopsis mycoparasitica as a destructive mycoparasite. Mycological Research 96, in press.

Walt, J. P. van der, \& Hopsu-Havu, V. K. (1976). A colour reaction for the differentiation of ascomycetous and hemibasidiomycetous yeasts. Antonie van Leeuwenhoek 42, 157-163. 